EETP Vol. 14, 2019, №. 2(52)

ISSN $1896-2327$ / e-ISSN 2353-7787

DOI: $10.35765 /$ eetp.2019.1452.06

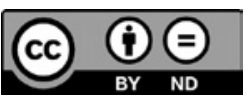

Nadesłano: 5.07. 2019

Zaakceptowano: 14.08.2019

Sugerowane cytowanie: Surma B. (2019). Ksztaftowanie kluczowych kompetencji nauczycieli edukacji elementarnej - raport z badań, "Edukacja Elementarna w Teorii i Praktyce”, vol. 14, nr 2(52), s. 93-104. DOI: 10.35765/eetp.2019.1452.06

\title{
Kształtowanie kluczowych kompetencji nauczycieli edukacji elementarnej - raport z badań
}

\section{Shaping Key Competences of Elementary Education Teachers - Research Report}

\section{SŁOWA KLUCZOWE ABSTRAKT}

\begin{tabular}{|c|c|}
\hline $\begin{array}{r}\text { kluczowe } \\
\text { kompetencje, } \\
\text { nauczyciel edukacji } \\
\text { przedszkolnej } \\
\text { i wczesnoszkolnej, } \\
\text { edukacja } \\
\text { elementarna, } \\
\text { program kształcenia } \\
\text { nauczycieli, wczesna } \\
\text { edukacja }\end{array}$ & $\begin{array}{l}\text { Celem artykułu jest zaprezentowanie badań pilotażowych przepro- } \\
\text { wadzonych wśród studentów drugiego roku studiów niestacjonar- } \\
\text { nych i stacjonarnych kierunku pedagogika ze specjalnością eduka- } \\
\text { cja przedszkolna i wczesnoszkolna oraz studentów pierwszego roku } \\
\text { uczestniczących w projekcie zatytułowanym: „Eksperymentalny pro- } \\
\text { gram kształcenia nauczycieli przedszkoli i edukacji wczesnoszkolnej } \\
\text { w AIK”. Projekt ten jest współfinansowany ze środków Unii Euro- } \\
\text { pejskiej w ramach Europejskiego Funduszu Społecznego, który ma } \\
\text { na celu podniesienie kompetencji osób uczestniczących w edukacji na } \\
\text { poziomie wyższym, odpowiadających potrzebom gospodarki, rynku } \\
\text { pracy i społeczeństwa, poprzez opracowanie i wdrożenie innowacyj- } \\
\text { nego programu kształcenia nauczycieli wczesnej edukacji. Badania } \\
\text { diagnostyczno-weryfikacyjne zostały przeprowadzone w czerwcu } \\
2019 \text { roku. Studenci oceniali swoje kluczowe kompetencje, które } \\
\text { uzyskali w trakcie procesu kształcenia. W celu ich porównania zasto- } \\
\text { sowano Test U Manna-Withneya. Analiza wyników badań pozwala } \\
\text { na ocenę realizowanych programów, które są podstawą do opracowa- } \\
\text { nia nowego modelu kształcenia kluczowych kompetencji nauczycieli } \\
\text { edukacji elementarnej. W artykule przedstawiono założenia progra- } \\
\text { mu kształcenia nauczycieli, podstawy metodologiczne przeprowadzo- } \\
\text { nych badań oraz analizę zgromadzonych wyników badań. }\end{array}$ \\
\hline
\end{tabular}




\section{KEYWORDS ABSTRACT}

key competences, The objective of the article is to present the results of pilot studies car-

kindergarten ried out among the second-year students of extramural and full-time

and early school studies in pedagogy with the specialisation: kindergarten and early teacher, elementary school pedagogy, and among the first-year students participating in education, the project entitled "Experimental programme of educating kinderteacher education garten and early school teachers at AIK". This project is co-financed programme, early from the European Union funds within the European Social Fund, education and its objective is to increase the competences of people participating in education at the university level in order to meet the needs of economy, labour market and society through the preparation and implementation of the innovative programme of educating teachers of early education. The diagnostic-verification research was carried out in June 2019. The students evaluated their key competences obtained in the process of education. In order to compare them, the U Mann-Withney Test was applied. The analysis of the results makes it possible to evaluate the programmes that are the basis for preparing a new model of shaping the key competences of elementary education teachers. The article presents the assumptions of the programme of educating teachers, the methodological bases for the research, and the analysis of the collected research results.

\section{Wprowadzenie}

W ramach Programu Operacyjnego Wiedza Edukacja Rozwój 2014-2020 współfinansowanego ze środków Europejskiego Funduszu Społecznego w Akademii Ignatianum w Krakowie (AIK) realizowany jest projekt: „Eksperymentalny program kształcenia nauczycieli przedszkoli i edukacji wczesnoszkolnej w AIK", który rozpoczął się 1 października 2018 roku i będzie trwał do 30 września 2023 roku. Celem projektu, zgodnie z założeniami szczegółowymi PO WER, jest podniesienie kompetencji osób uczestniczących w edukacji na poziomie wyższym, odpowiadających potrzebom gospodarki, rynku pracy i społeczeństwa, poprzez opracowanie i wdrożenie innowacyjnego programu kształcenia nauczycieli wczesnej edukacji. Równocześnie projekt ma pomóc w stworzeniu nowego modelu kształtowania kluczowych kompetencji przyszłych nauczycieli edukacji elementarnej.

Działania Akademii Ignatianum wpisują się w planowaną reformę szkolnictwa wyższego, która zakłada, że od 1 października 2019 roku studenci będą przygotowywani do wykonywania zawodu nauczycielskiego tylko na kierunku pedagogika przedszkolna i wczesnoszkolna w systemie jednolitych studiów magisterskich. Projekt 
stanowi odniesienie praktyczne dla reorganizacji procesu kształcenia nauczycieli realizowanego na AIK. Celem artykułu jest przedstawienie wyników badań pilotażowych przeprowadzonych wśród studentów z grupy eksperymentalnej z pierwszego roku studiów stacjonarnych i studentów z drugiego roku studiów stacjonarnych i niestacjonarnych, którzy oceniali swoje kluczowe kompetencje. Wyniki te przyczynią się do wstępnej weryfikacji realizowanego programu kształcenia nauczycieli i pozwolą na wprowadzenie niezbędnych w nim modyfikacji. Artykuł składa się z trzech części: w pierwszej przedstawione zostaną wstępne założenia programu kształcenia nauczycieli, w drugiej zarysowane zostaną podstawy metodologiczne, w trzeciej analiza wyników badań.

\section{Założenia eksperymentalnego programu kształcenia nauczycieli przedszkoli i edukacji wczesnoszkolnej}

W latach 2016-2017 zespół wyłoniony w konkursie dofinansowanym przez Ministerstwo Nauki i Szkolnictwa Wyższego i EFS podjął się realizacji projektu zatytułowanego „Opracowanie modelowych programów kształcenia nauczycieli” w ramach działania 3.1 Kompetencje w szkolnictwie wyższym. Celem badań było „przygotowanie pogłębionej analizy porównawczej dotyczącej systemu kształcenia nauczycieli w wybranych krajach europejskich oraz zaleceń w zakresie zmian systemu kształcenia nauczycieli w Polsce, i opracowanie modelowych programów kształcenia nauczycieli w szkołach wyższych" (www.archiwum.nauka.gov.pl [dostęp: 31.01.2018]).

Dokument „Propozycja nowego modelu kształcenia nauczycieli przedszkoli i edukacji wczesnoszkolnej" (www.archiwum.nauka.gov.pl/g2/oryginal/2018_03/ cac95e27a335dcdb00979556332feb00.pdf [dostęp: 31.01.2018]) opublikowany 31 stycznia 2018 roku stał się podstawą kolejnego konkursu, do którego przystąpiła również Akademia Ignatianum w Krakowie. Bazując na wytycznych zawartych w tym dokumencie, opracowano wstępne założenia „Eksperymentalnego programu kształcenia nauczycieli przedszkoli i edukacji wczesnoszkolnej w Akademii Ignatianum w Krakowie" ${ }^{1}$. W proponowanym modelu kształcenia nauczycieli autorzy w opisie sylwetki absolwenta zwrócili szczególną uwagę na potrzebę kształtowania kompetencji nauczycielskich. Kompetencje te ujęto w dwóch obszarach: 1) wiedzy i umiejętności o charakterze profesjonalnym; 2) kształtowania relacji wobec siebie i innych. Uszczegóławiając je, zapisano, że osoba kończąca pięcioletni cykl kształcenia powinna być: refleksyjnym praktykiem, ekspertem od wspierania rozwoju dziecka i erudytą

Projekt współfinansowany ze środków Unii Europejskiej w ramach Europejskiego Funduszu Społecznego. 
posiadającym interdyscyplinarną i zinterioryzowaną wiedzę o świecie (tamże, s. 1). W ramach drugiego obszaru natomiast absolwent będzie:

spolegliwym opiekunem;

członkiem zespołu/ów;

człowiekiem pozytywnie nastawionym do nowych doświadczeń;

osobą mającą świadomość swoich zainteresowań;

- człowiekiem uczciwym, starającym się działać na podstawie uniwersalnych zasad etycznych.

W dokumencie tym szczegółowo opisano również efekty kształcenia w zakresie wiedzy, umiejętności, kompetencji społecznych i interpersonalnych, własnego rozwoju, technologii informacyjnej i komunikacyjnej oraz informatyki, a także języka obcego (tamże, s. 2-8), które należało zaplanować w nowo powstającym programie kształcenia nauczycieli. W zaproponowanych modułach wskazano przybliżoną liczbę godzin przeznaczoną na realizację treści, jednocześnie dając możliwość uczelniom przystępującym do konkursu na ich modyfikację i przesunięcia według własnego innowacyjnego podejścia.

W stosunku do poprzedniego programu kształcenia nauczycieli położono większy nacisk na bezpośrednie skorelowanie treści z poszczególnych modułów z uczeniem się w działaniu. Jednym z rozwiązań dla tego postulatu jest połączenie zajęć odbywających się na uczelni z praktykami w placówkach przedszkolnych i klasach I-III. Praktyki mają się odbywać już na pierwszym roku studiów (dotychczas na studiach pierwszego stopnia praktyki wprowadzające były realizowane dopiero na drugim roku). To praktyczne umocowanie zostało uzasadnione koniecznością interdyscyplinarnego rekonstruowania i konstruowania treści bez sztucznego podziału na dyscypliny, ale także postulatami studentów, którzy zwracali uwagę na łączenie teorii z praktyką. Efektem takich działań ma być uzyskanie kompetencji pozwalającej absolwentom na prowadzenie „skutecznej i profesjonalnej propedeutyki przedmiotów takich jak: język polski, historia, przyroda, matematyka, plastyka, muzyka, technika i informatyka" (tamże, s. 1), ale także stawanie się refleksyjnym praktykiem czy też człowiekiem pozytywnie nastawionym do nowych doświadczeń i współpracy z innymi nauczycielami. W opracowanym przez zespół modelu zaproponowano również działania mające służyć indywidualnemu wsparciu studenta w jego dążeniu do osiągnięcia dojrzałości i gotowości do pracy nauczyciela. Zrezygnowano też z przedmiotów ogólnoakademickich, które były realizowane na pierwszym roku studiów, na rzecz modułu pedagogiczno-psychologicznego, zawierającego podstawy: pedagogiki (wiedza o świecie, o relacjach ja - świat, o sobie samym), pedagogiki przedszkolnej i wczesnoszkolnej oraz psychologii dla nauczycieli.

W eksperymentalnym programie stworzonym dla potrzeb AIK uwzględniono najważniejsze założenia określone w omawianym dokumencie związane z kształtowaniem 
kompetencji nauczycieli przedszkola i klas I-III dla pięcioletniego cyklu kształcenia. Między innymi zaplanowano:

- przeprowadzenie warsztatów rozwoju osobistego i treningu komunikacyjnego;

- indywidualne spotkania z elementami tutoringu, przygotowujące do uczenia się przez całe życie, radzenia sobie ze stresem i przeciwdziałania wypaleniu zawodowemu (20 godzin w całym cyklu kształcenia);

- łączenie wiedzy z praktyką polegające na integracji zajęć teoretycznych realizowanych na uczelni z praktyką i obserwacją pracy w placówkach przedszkolnych i wczesnoszkolnych;

- zmniejszenie liczebności grup ćwiczeniowych do ośmiu osób;

- wprowadzenie innowacyjnych metod kształcenia nauczycieli (m.in. laboratoryjne, e-learningowe, projektowe, heurystyczne, badania w działaniu);

- zapoznanie z zagranicznymi rozwiązaniami w zakresie nauczania matematyki dzieci oraz wspierania rozwoju dzieci w systemie pedagogicznym Montessori;

- zwiększenie godzin przygotowujących studentów do prowadzenia zajęć z muzyki, rytmiki, plastyki.

Założeniem projektu jest w szczególności podniesienie kompetencji poznawczych, wychowawczo-dydaktycznych, diagnostycznych, innowacyjnych, organizatorskich, społecznych i interpersonalnych oraz umiejętnego posługiwania się i wykorzystywania technologii informacyjnej i komunikacyjnej w nauce i przyszłej pracy nauczycieli przedszkoli i edukacji wczesnoszkolnej. Studenci oraz nauczyciele sprawujący opiekę nad praktykami w placówkach przedszkolnych i wczesnoszkolnych będą zachęcani do wzięcia udziału w międzynarodowym projekcie „Kitchen Lab for Kids” dofinansowanym przez Erasmus Plus. Akcja 2, którego celem jest dzielenie się dobrymi praktykami w zakresie edukacji STEM w przedszkolu (więcej na temat projektu: http://kitchenlab4kids.eu/ [dostęp: 01.-06.2019])². Wymiana doświadczeń między studentami a nauczycielami oraz wspólne inicjatywy mają na celu zwiększenie ich aktywności na rzecz poszukiwania nowych rozwiązań w pracy z dzieckiem/uczniem.

\section{Metodologiczne podstawy badań własnych}

Badania diagnostyczno-weryfikacyjne zostały przeprowadzone na początku czerwca 2019 roku wśród studentów z grupy eksperymentalnej z pierwszego roku studiów stacjonarnych oraz dla porównania w grupie studentów drugiego roku studiów stacjonarnych i niestacjonarnych. Ponieważ studenci nie zakończyli jeszcze procesu

2 Jeden z kolejnych numerów EETP będzie podejmował zagadnienia związane z edukacją STEM, czyli rozwijaniem myślenia naukowego w przedszkolu. 
kształcenia, nie badamy poziomu ich kompetencji zawodowych, ale to, jak oceniają oni swoje kluczowe kompetencje.

Wprowadzone zmiany $\mathrm{w}$ eksperymentalnym programie kształcenia nauczycieli przedszkola i klas I-III pozwalają na przeprowadzenie badań wśród studentów $\mathrm{z}$ dwóch różnych roczników, bowiem treści realizowane na pierwszym roku (grupa eksperymentalna) i na drugim roku są w pewnym stopniu porównywalne. Trzeba jednak pamiętać, że studenci drugiego roku mieli większą liczbę godzin zajęć przygotowujących merytorycznie do pracy w przedszkolu i szkole (dwa semestry, grupa eksperymentalna tylko jeden semestr, ponieważ w pierwszym semestrze realizowany był program ogólnoakademicki). Odbyli też o 30 godzin więcej praktyk w placówkach oświatowych (nie zawsze to były przedszkola i klasy I-III). Grupa eksperymentalna natomiast zrealizowała 30 godzin praktyk wprowadzających tylko w przedszkolach. Były one ściśle skorelowane z zajęciami z pedagogiki przedszkolnej oraz obserwacją dziecka w przedszkolu z planowaniem działań edukacyjnych, zgodnie z założeniami nowego modelu kształcenia. Trzeba też podkreślić, że zajęcia w grupie eksperymentalnej, w przeciwieństwie do pozostałych dwóch grup, odbywały się w małych grupach, co pozwalało na indywidulne podejście i wsparcie studentów w zakresie ich przygotowania do zawodu nauczyciela.

Problematyka badawcza dotyczyła zatem trzech kwestii zawartych w pytaniach:

1. Jak badani studenci oceniają swoje kluczowe kompetencje, które rozwijali w szkole podstawowej i średniej?

2. Jak oceniają swoje aktualne kompetencje nauczycielskie?

3. Czy między uzyskanymi wynikami w trzech badanych grupach występują statystycznie istotne różnice?

W celu zgromadzenia wyników badań zastosowano metodę ankiety ze skalowaniem oraz dla porównania wyników w dwóch niezależnych grupach Test U Manna-Whitneya. Struktura ankiety została oparta na analizie dostępnej literatury (m.in. Strykowski 2005; Ordon 2009; Adamek 2014; Śliwa 2017).

Kwestionariusz ankiety składał się z dwóch części. W pierwszej badani oceniali pięć kompetencji, które jako kluczowe kształtowane były w szkole podstawowej i średniej. W drugiej oceniali swoje aktualne kompetencje jako przyszłego nauczyciela. W tym przypadku było to 20 wybranych kompetencji, które wynikały z realizowanych programów kształcenia. Zaproponowano czterostopniową skalę ocen. Przy założeniu, że studenci z grupy eksperymentalnej nie realizowali w takim samym stopniu treści co studenci drugiego roku, uznajemy, że mogą występować różnice między uzyskanymi wynikami.

Badana grupa liczyła 120 osób, w tym 70 osób z drugiego roku studiów niestacjonarnych (grupa 1), 30 osób z drugiego roku studiów stacjonarnych (grupa 2) oraz z pierwszego roku z grupy eksperymentalnej 20 osób (grupa 3). 


\section{Analiza wyników badań}

W celu uzyskania odpowiedzi na pierwsze pytanie problemowe dotyczące poziomu kluczowych kompetencji ukształtowanych w szkole podstawowej i średniej poproszono badanych, by w skali od 1 do 4 ocenili następujące sformułowania:

1. Umiem planować, organizować i oceniać własne uczenie się.

2. Potrafię skutecznie porozumiewać się w różnych sytuacjach.

3. Potrafię efektywnie współdziałać w zespole.

4. Rozwiązuję w sposób twórczy problemy.

5. Sprawnie posługuję się komputerem.

Otrzymane wyniki miały wykazać ewentualne różnice w ocenie kompetencji między grupami badanych studentów. Zakładamy, że występowanie istotnych statystycznie różnic w ocenie kompetencji może warunkować dalszy proces ich kształtowania. Wyniki w poszczególnych kategoriach zostały poddane badaniu Testem U Manna-Whitneya.

Jeśli chodzi o ocenę kompetencji przed rozpoczęciem studiów, w pierwszych pięciu kategoriach statystycznie istotną różnicę $(\mathrm{p}=0,03)$ odnotowano tylko w ocenie piątej kompetencji dotyczącej sprawnego posługiwania się komputerem. Studenci drugiego roku studiów niestacjonarnych (grupa 1) wyżej ocenili swoje kompetencje w porównaniu z grupą drugą (tab. 1). Nie odnotowano różnicy między ocenami w grupie pierwszej i trzeciej oraz w drugiej i trzeciej.

Tabela 1. Sprawnie posługuję się komputerem

\begin{tabular}{|c|c|c|c|c|}
\hline Skala ocen & $\begin{array}{c}\text { Grupa 1 } \\
(\mathbf{2} \text { rok SN) }\end{array}$ & $\begin{array}{c}\text { Grupa 2 } \\
\text { (2 rok SS) }\end{array}$ & $\begin{array}{c}\text { Grupa 3 } \\
\text { (1 rok GE) }\end{array}$ & Razem \\
\hline 4 & 41 & 10 & 8 & 59 \\
\hline 3 & 21 & 15 & 5 & 41 \\
\hline 2 & 4 & 3 & 6 & 13 \\
\hline 1 & 4 & 2 & 1 & 7 \\
\hline Razem & 70 & 30 & 20 & 120 \\
\hline
\end{tabular}

Źródło: opracowanie własne.

Badani studenci ocenili poziom swoich kompetencji kluczowych na podobnym poziomie. Jak wskazano wyżej, jedyną różnicę w ocenie stanowiły kompetencje informatyczne. Ponieważ w programie kształcenia nauczycieli zakłada się realizację treści z technologii informacyjno-komunikacyjnej, przygotowującej do skutecznego 
korzystania z TIK również w pracy z dziećmi (wyjaśnienie, na czym polegają kompetencje informatyczne nauczycieli, zob. Ordon, Serwatko 2016), w drugiej części ankiety zapytano ponownie o ocenę tejże kompetencji, ale z uszczegółowieniem o umiejętność korzystania z technologii informacyjnej podczas prowadzenia zajęć z dziećmi. Wyniki zaprezentowano w tabeli 2.

Tabela 2. Nie mam problemów, aby prowadzić zajęcia z korzystaniem z technologii informacyjnej

\begin{tabular}{|c|c|c|c|c|}
\hline Skala ocen & Grupa 1 & Grupa 2 & Grupa 3 & Razem \\
\hline 4 & 35 & 16 & 11 & 62 \\
\hline 3 & 22 & 9 & 5 & 36 \\
\hline 2 & 11 & 4 & 4 & 19 \\
\hline 1 & 2 & 1 & 0 & 3 \\
\hline Razem & 70 & 30 & 20 & 120 \\
\hline
\end{tabular}

Źródło: opracowanie własne.

Studenci studiów niestacjonarnych, w porównaniu z pierwszą oceną, zdecydowanie słabiej ocenili swoje kompetencje w tym zakresie, w przeciwieństwie do studentów z grupy drugiej i trzeciej. Wyniki w tym przypadku nie wykazały różnic statystycznie istotnych. Różnica została zatem zniwelowana. Niższa ocena studentów z pierwszej grupy może wynikać z mniejszej liczby godzin przeznaczonych na zajęcia z TIK i metodyk szczegółowych oraz zbyt licznych grup ćwiczeniowych. Wysoka ocena umiejętności posługiwania się komputerem nie przełożyła się na sprawne korzystanie z TIK w celu prowadzenia zajęć.

W drugiej części ankiety badani studenci oceniali wybrane kompetencje nauczycielskie, które wynikały z ich programu kształcenia, w tym: merytoryczne, dydaktyczne, organizacyjne, poznawcze, psychologiczne, ale też komunikacyjne i społeczne. Badani oceniali następujące sformułowania:

1. Umiem zaplanować zajęcia $\mathrm{z}$ dziećmi zgodnie $\mathrm{z}$ wymaganiami metodycznymi.

2. Umiem zaplanować cele i sprawdzić, czy zostały osiągnięte.

3. Potrafię efektywnie włączać uczniów w proces uczenia się.

4. Potrafię kierować aktywnością dzieci tak, aby były skoncentrowane i zainteresowane.

5. Znam metody pracy z dziećmi w przedszkolu.

6. Wiem, na czym polega proces zintegrowanego nauczania.

7. Potrafię współpracować z nauczycielami. 
8. Interpretuję pracę nauczyciela (potrafię ocenić jego dobre i złe podejście do dzieci).

9. Mam wystarczającą wiedzę przedmiotową, by uczyć matematyki.

10. Mam wystarczającą wiedzę przedmiotową, by uczyć przyrody.

11. Mam wystarczającą wiedzę przedmiotową, by uczyć języka polskiego.

12. Nie mam problemów, aby prowadzić zajęcia z dziećmi z korzystaniem z technologii informacyjnej.

13. Mam wystarczające umiejętności i wiedzę, by diagnozować rozwój i proces uczenia się dzieci.

14. Jestem pozytywnie nastawiona do zdobywania nowej wiedzy.

15. Wiem, że trzeba się wciąż doskonalić.

16. W pracy z dziećmi kieruję się empatią.

17. Jestem przygotowana do pracy z rodzicami.

18. Nie mam problemów z nawiązywaniem kontaktów z innymi.

19. Nie mam problemów z komunikacją interpersonalną.

20. Znam swoje mocne i słabe strony.

Wyniki podobnie jak poprzednio poddane zostały analizie statystycznej. Test U Manna-Withneya wykazał statycznie istotne różnice między grupą pierwszą i drugą w pięciu badanych kategoriach. We wszystkich przypadkach studenci drugiego roku studiów niestacjonarnych (grupa 1) wyżej ocenili swoje kompetencje niż studenci tego samego roku studiujący w systemie stacjonarnym. Różnice występowały w następujących zakresach:

1. Wiem, na czym polega proces zintegrowanego uczenia się $\mathrm{p}=0,02$.

2. Interpretuję pracę nauczyciela (potrafię ocenić jego dobre i złe podejście do dzieci) $\mathrm{p}=0,01$.

3. Mam wystarczającą wiedzę przedmiotową, by uczyć matematyki $\mathrm{p}=0,03$.

4. Wiem, że trzeba się doskonalić $\mathrm{p}=0,04$.

5. W pracy kieruję się empatią $\mathrm{p}=0,01$.

Odnotowane różnice w ocenie kompetencji wśród studentów realizujących ten sam program kształcenia mogą być związane z większym doświadczeniem studentów studiów niestacjonarnych, ale też z innym poziomem świadomości czy oczekiwań społecznych. Oceny te powinny być dodatkowo zweryfikowane testami kompetencyjnymi.

Między otrzymanymi wynikami w grupie pierwszej (drugi rok studiów niestacjonarnych) a grupą eksperymentalną (pierwszy rok studiów stacjonarnych) statystycznie istotne różnice odnotowano w ocenach następujących kompetencji:

1. Wiem, na czym polega proces zintegrowanego uczenia się $\mathrm{p}=0,01$.

2. Potrafię współpracować $\mathrm{z}$ nauczycielami $\mathrm{p}=0,001$. 
3. Mam wystarczającą wiedzę przedmiotową, by uczyć przyrody $\mathrm{p}=0,05$.

4. Mam wystarczające umiejętności i wiedzę, by diagnozować rozwój i proces uczenia się dzieci $\mathrm{p}=0,003$.

5. W pracy z dziećmi kieruję się empatią $\mathrm{p}=0,01$.

6. Jestem przygotowana do pracy $\mathrm{z}$ rodzicami $\mathrm{p}=0,001$.

Różnice występujące między tymi grupami są wynikiem realizowanego programu, który w przypadku grupy eksperymentalnej na tym etapie nie uwzględniał zajęć kształtujących wyżej wymienione kompetencje.

Kolejnym etapem było porównanie wyników między studentami z drugiego roku studiów stacjonarnych (grupa 2) i z pierwszego roku studiów stacjonarnych - grupą eksperymentalną (grupa 3). Statystycznie istotne różnice odnotowano również w ocenach sześciu kompetencji:

1. Umiem zaplanować cele i sprawdzić, czy zostały osiagnięte $\mathrm{p}=0,002$.

2. Znam metody pracy z dziećmi w przedszkolu $\mathrm{p}=0,03$.

3. Wiem, na czym polega proces zintegrowanego nauczania $\mathrm{p}=0,0002$.

4. Potrafię współpracować $\mathrm{z}$ nauczycielami $\mathrm{p}=0,006$.

5. Intepretuję pracę nauczyciela (potrafię ocenić jego dobre i złe podejście do dzieci) $\mathrm{p}=0,009$.

6. Mam wystarczające umiejętności i wiedzę, by diagnozować rozwój i proces uczenia się dzieci $\mathrm{p}=0,01$.

Ponownie kompetencje dotyczące procesu zintegrowanego nauczania, współpracy z nauczycielami i diagnozowania procesu uczenia się dzieci zostały lepiej ocenione przez studentów drugiego roku studiów stacjonarnych, co potwierdza różnice w realizacji programu. Studenci drugiego roku studiów stacjonarnych zdecydowanie lepiej ocenili też swoje kompetencje w zakresie planowania celów i ich oceniania, metod pracy $\mathrm{w}$ przedszkolu czy też interpretowania pracy nauczyciela. W tym przypadku można przypuszczać (analizując wyniki egzamin z poszczególnych przedmiotów), że studenci pierwszego roku posiadają podstawową wiedzę i umiejętności, ale w ich opinii nie są one jeszcze na wystarczającym poziomie. Wymagają utrwalenia, co będzie realizowane w kolejnych latach ich edukacji.

\section{Wnioski z badań}

Badania porównawcze wykazały tylko w niektórych ocenach kompetencji nauczycielskich różnice statystycznie istotne. Wystąpiły one zarówno między studentami realizującymi ten sam program, jak i między studentami z grupy eksperymentalnej 
i studentami z drugiego roku. W związku z tym, że w ocenach pozostałych kompetencji nie zaszły istotne statystycznie różnice, można stwierdzić, że realizowany nowy program spełnia swoje założenia już na tym etapie. Należy też zwrócić uwagę na dalsze utrwalanie kompetencji metodycznych, diagnostycznych, komunikacyjno-społecznych i organizatorskich wszystkich studentów.

Kompetencje praktyczne i interpersonalne muszą być wspierane działaniem w praktyce, co obrazują wyniki wskazujące istotne różnice między studentami drugiego roku studiów niestacjonarnych i stacjonarnych. Badania potwierdzają słuszność rozpoczęcia odbywania praktyk już na pierwszym roku studiów. Zwiększenie liczby godzin przewidzianych na praktyki, bez integracji z innymi przedmiotami realizowanymi na uczelni, nie przyniesie oczekiwanych efektów. Studenci pierwszego i drugiego roku studiów stacjonarnych gorzej ocenili swoje kompetencje w zakresie intepretowania pracy nauczyciela, oceny jego dobrego i złego podejścia do dzieci, co może potwierdzać potrzebę omawiania praktyk i dzielenia się zgromadzonymi doświadczeniami z nauczycielami akademickimi.

W celu stworzenia modelu kształtowania kompetencji nauczycieli edukacji elementarnej należy w dalszym ciągu monitorować zakładane efekty i wspólnie ze studentami i nauczycielami współpracującymi z Akademią Ignatianum modyfikować i zintensyfikować działania na rzecz poprawienia jakości pracy.

\section{Bibliografia}

Adamek I. (2014). Kompetencje kluczowe a swoistość kompetencji kreatywnych, [w:] I. Adamek, J. Bałachowicz (red.), Kompetencje kreatywne nauczyciela wczesnej edukacji, Kraków: Oficyna Wydawnicza Impuls, s. 15-47.

Ordon U. (2009). Samoocena kompetencji zawodowych nauczycieli przedszkoli i klas I-III wobec wymogów edukacji europejskiej, [w:] I. Adamek, E. Żmijewska (red.), Nauczyciel w systemie edukacyjnym: teraźniejszość i przysztość, Kraków: Wydawnictwo Naukowe Uniwersytetu Pedagogicznego, s. 66-76.

Ordon U., Serwatko K. (2016). Kompetencje informatyczne w samoocenie nauczycieli edukacji przedszkolnej i wczesnoszkolnej, „Edukacja - Technika - Informatyka”, nr 3/17. DOI: 10.15584/eti.2016.3.23

Strykowski W. (2005). Kompetencje wspótczesnego nauczyciela, „Neodidagmata”, [t.] 27/28, s. $15-28$.

Śliwa S. (2017). Kompetencje profilaktyczne nauczycieli edukacji wczesnoszkolnej, Opole: Wydawnictwo Instytut Śląski. 
Netografia

Kitchen Lab for Kids, http://kitchenlab4kids.eu/ (dostęp: 01.06.2019).

Propozycja nowego modelu ksztatcenia nauczycieli przedszkoli i edukacji wczesnoszkolnej, www.archiwum.nauka.gov.pl/g2/oryginal/2018_03/cac95e27a335dcdb0097955 6332feb00.pdf (dostęp: 31.01.2018).

\section{ADRES DO KORESPONDENCJI}

dr hab. Barbara Surma, prof. AIK

Wydział Pedagogiczny

Akademia Ignatianum w Krakowie

e-mail: barbara.surma@ignatianum.edu.pl 